Arch. histol. jap., Vol. 39, No. 5 (1976) p. $327-332$

\author{
Department of Anatomy (Prof. H. OutI), Okayama University School of Medicine, \\ Okayama, Japan
}

\title{
Double Afferent Arterioles of the Rat Renal Glomerulus as Studied by the Injection Replica Scanning Electron Microscope Method
}

\author{
Takuro MuRAKami
}

Received June 29, 1976

\begin{abstract}
Summary. One thousand eight hundred and fifty-six specimens of replicated rat renal glomerulus were examined under the scanning electron microscope, and an extremely rare anomaly of the glomerulus with double afferent arterioles was described.

The double afferent arterioles arose separately from a terminal twig of the interlobular artery and reached the vascular pole of a subcapsular glomerulus which possessed a single efferent arteriole. Microdissection revealed that this glomerulus was composed of three fairly independent lobules of anastomosing capillaries. Microdissection also revealed that the double afferent arterioles were isolated from each other even in the glomerulus; the one supplied two lobules, while the other the third one only.
\end{abstract}

By combining the plastic casting of blood vessels with scanning electron microscopy (MuraKami, 1971), it was clearly demonstrated that the renal glomerulus occasionally gives off double or paired efferent vessels (MURAKAmI et al., 1971).

Our recent reinvestigation of the rat renal glomerulus by that method has proved that the vascular duplication may occur also in the afferent arteriole, which will be described in this paper.

\section{Materials and Methods}

One thousand eight hundred fifty-six glomeruli were isolated together with their connecting vessels from the methyl methacrylate vascular casts of adult rat kidneys, which had been prepared during the course of our previous studies (MURAKAmI et al., 1971; Murakami, 1972). The isolated glomeruli were coated with gold and observed under a scanning electron microscope (JSM-U3) using an acceleration voltage of $5 \mathrm{kV}$. In order to expose the inner aspects of the glomerulus, microdissection with sharpened forceps was also performed as in our previous studies (Murakami et al., 1971; MuraKAmI, 1972).

\section{Observations and Discussion}

In 1839 out of the 1856 cases examined in the present study, the glomerulus was normally provided with single afferent and single efferent arterioles. (These 1839 cases contain the 69 glomeruli in which the efferent arteriole showed precocious branching at the vascular pole. cf. MuRAKami et al., 1971). In 16 cases the glomerulus had single afferent and double efferent arterioles while in one case it had double afferent and single efferent arterioles.

Microdissection, using 20 of the normal 1839 glomeruli and 4 of the 16 glomeruli with double efferent arterioles, revealed that the glomeruli were formed by lobulated capillary networks and that the double efferent arterioles were separately derived 


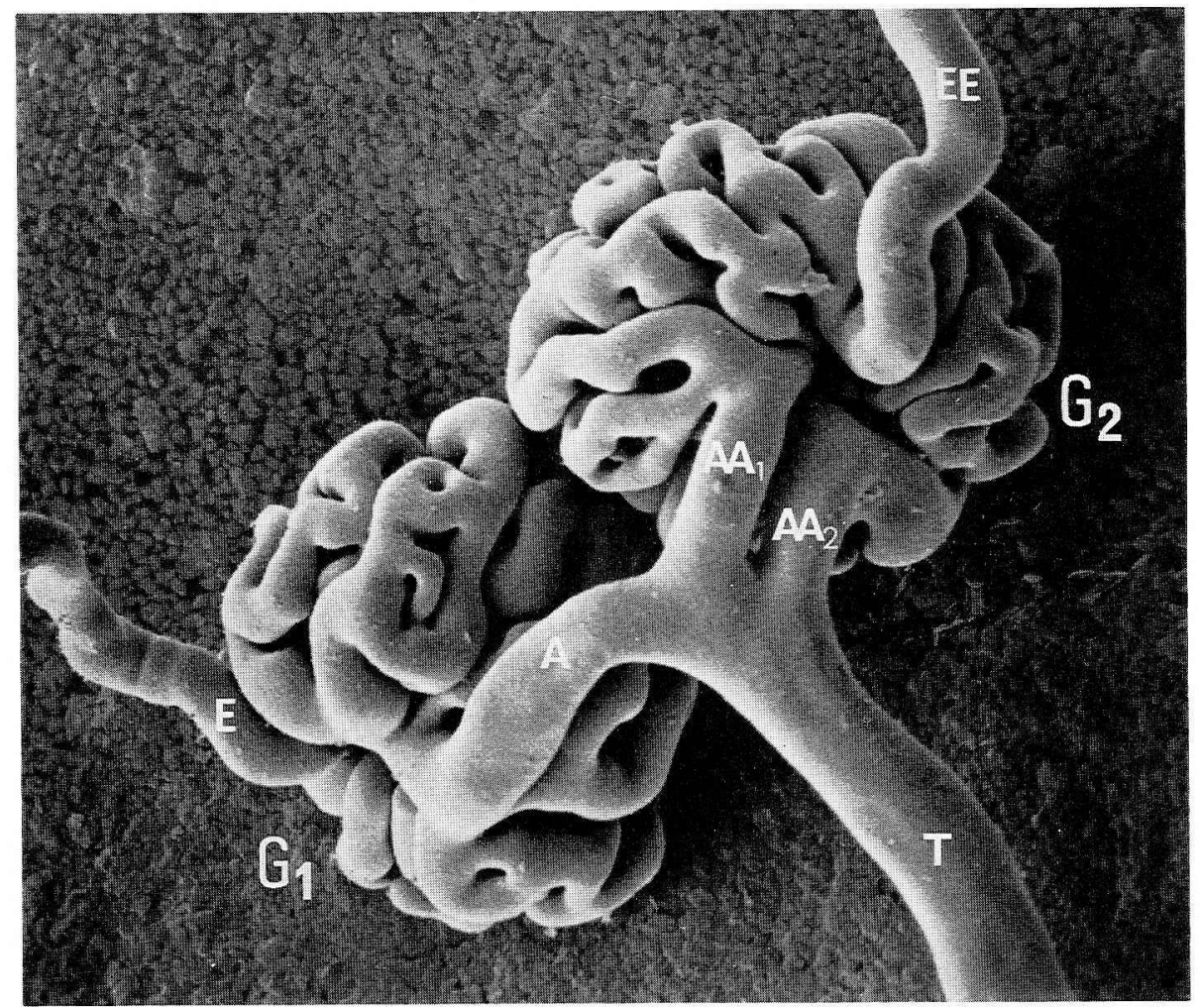

Fig. 1. A scanning electron micrograph of methyl methacrylate vascular cast reproducing a rare rat renal glomerulus with double afferent arterioles. Note that the right-sided glomerulus $\left(G_{2}\right)$ receives paired or double afferent arterioles $\left(A A_{1}, A A_{2}\right)$, in contrast to the left-sided glomerulus $\left(G_{1}\right)$ with single afferent arteriole $(A)$. $E$ efferent arteriole of $G_{1}$ glomerulus, $E E$ efferent arteriole of $G_{2}$ glomerulus, $T$ terminal twig of the interlobular artery. $\quad \times 500$

from different lobules. These findings coincided altogether with those of our previous studies (Murakami et al., 1971; Murakami, 1972). Thus, the present description will be concentrated on the case with double afferent arterioles not encountered previously.

A terminal twig of the interlobular artery isolated near the upper pole of a left kidney branched into three arterioles and supplied two subcapsular glomeruli (Fig. 1). One $(A)$ of the three arterioles terminated as usual in one glomerulus $\left(G_{1}\right)$, while the other paired ones $\left(A A_{1}, A A_{2}\right)$ ran parallel for a short distance and reached the vascular pole of another glomerulus $\left(G_{2}\right)$ (Fig. 1).

The latter unusual glomerulus with double afferent arterioles could be microdissected into three lobules (Fig. 2, 3). The left-sided vessel $\left(A A_{1}\right)$ of the double afferent arterioles supplied solely the left-sided lobule $(L)$, while the right-sided one $\left(A A_{2}\right)$ continued into the middle and right-sided lobules $(M, R)$ (Fig. 2, 3).

Each of the three lobules consisted of capillaries with multiple anastomoses and were fairly independent of each other (Fig. 2, 3). Interlobular communication was only noted at the distal segments of the lobules $(d, e, f)$ (Fig. 3 ). The proximal and 


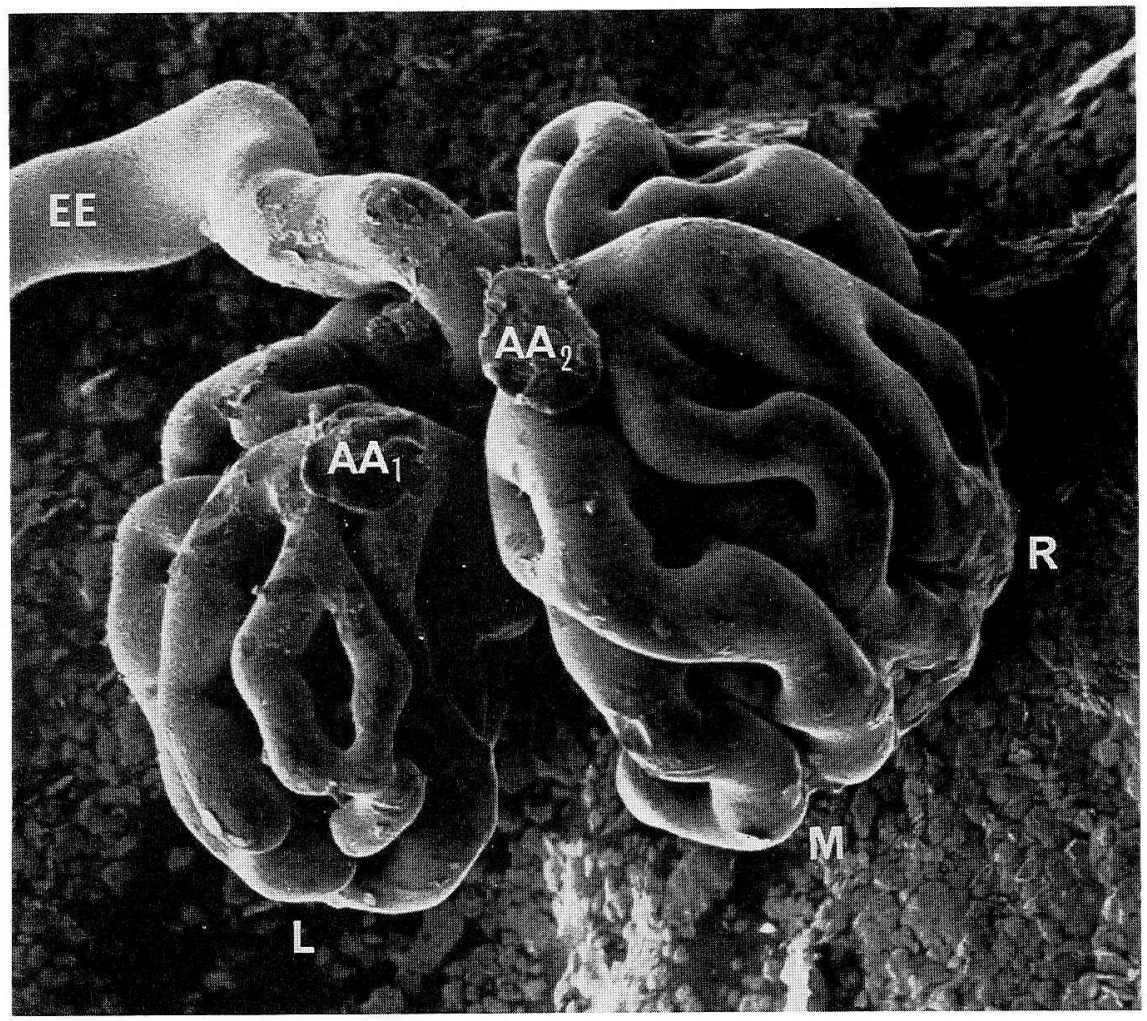

Fig. 2. A microdissected form of the $G_{2}$ glomerulus with double afferent arterioles shown in Figure 1. Note that the left-sided afferent arteriole $\left(A A_{1}\right)$ continues into the left-sided lobule $(L)$ only, while the right-sided one $\left(A A_{2}\right)$ supplies the middle $(M)$ and right-sided $(R)$ lobules. $E E$ efferent arteriole.

distal segments of the lobules were completely separated by a gap opening to the vascular pole (arrows) (Fig. 3).

As unequivocally shown in our previous paper (MURAKami, 1972), the glomerulus is formed by the lobulated networks of anastomosing capillaries with neither a preferential nor a short-cut pathway from the afferent to efferent arterioles. In this respect the herein described unusual glomerulus with double afferent arterioles is not different from normal ones.

The blood vessels, including the afferent arteriole, of the renal glomerulus have been studied using various samples of man, monkey, dog, rabbit, rat and other animals by many researchers (Johnston, 1899; Nelson, 1922; Moore, 1928; Boenig, 1936; Wilmer, 1941; Trabucco and Marquez, 1952; Ohta and Tajiri, 1954; Hall, 1955; Boyer, 1956; Elias, 1957; Lewis, 1958; Kojima, 1961; Muto, 1961; Luungqvist and Lagergren, 1962; Moffat and Fourman, 1963; Osathanondh and Potter, 1966; ZLÁBEK, 1973; and others). As far as we know, however, a glomerulus with double afferent arterioles has not been reported by the previous authors. It was not encountered even in our foregoing 1,200 or more cases of casted glomeruli of adult and new- 


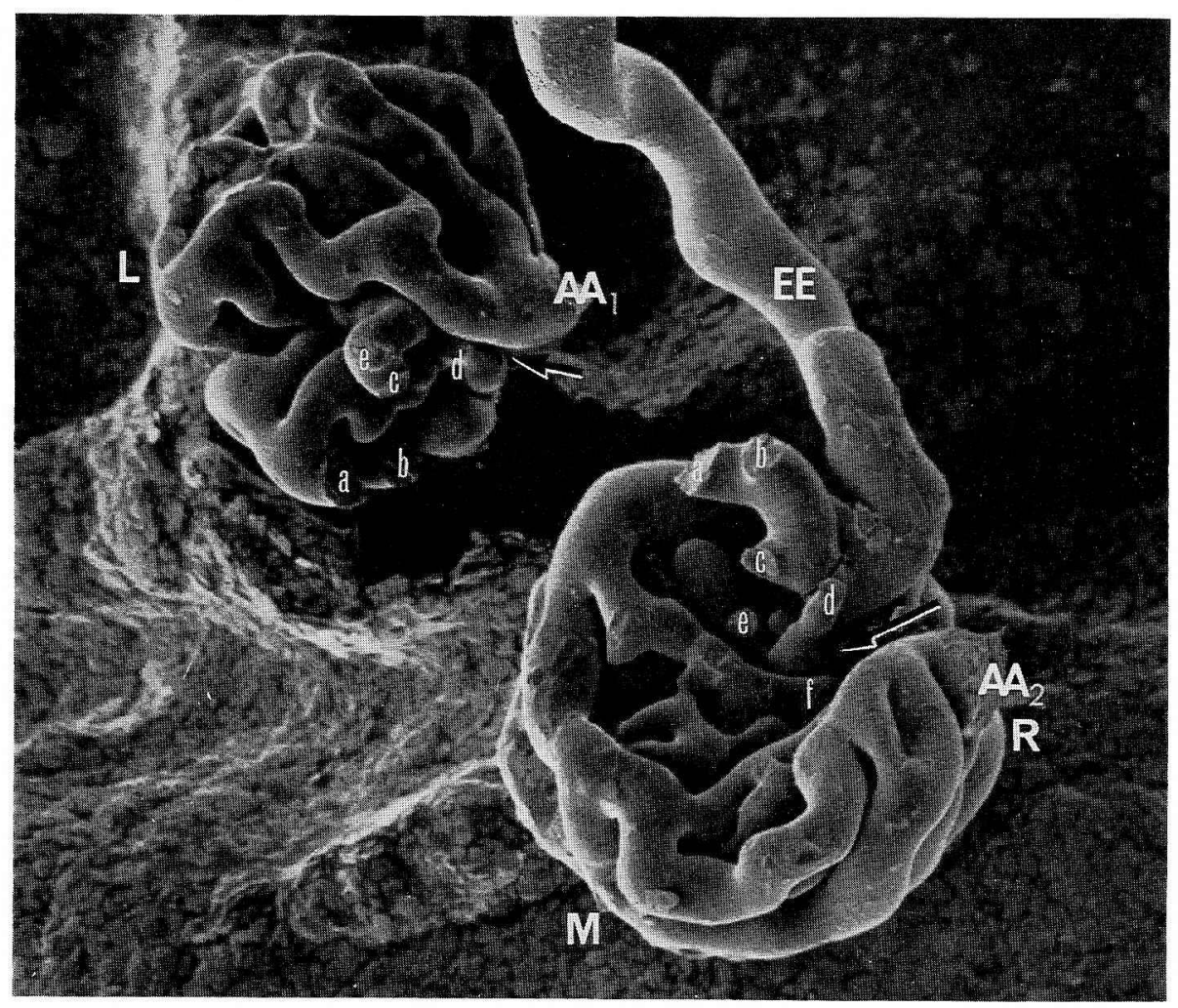

Fig. 3. Further microdissected form of the $G_{2}$ glomerulus shown in Figure 1. Note that the left-sided lobule $(L)$ supplied by the left-sided arteriole $\left(A A_{1}\right)$ is isolated as a fairly independent unit from the middle and right-sided lobules $(M, R)$ derived from the right-sided arteriole $\left(A A_{2}\right)$. $E E$ efferent arteriole; $a, b, c$ cut-edges of the distal convergences of $L$ lobule; $d, e$ cut-edges of the interlobular capillaries communicating with the $L$ and $M$ lobules; $f$ interlobular capillary between the $M$ and $R$ lobules; arrows gaps separating the proximal and distal segments of the lobules.

born rats (Murakami et al., 1971; Murakami, 1972). The double afferent arterioles were also never noticed in our preliminary study of casted human fetal and senile samples (IRINO et al., 1974). These circumstances indicate that the occurrence of the double afferent arterioles is very rare.

Acknowledgement. The author expresses his sincere thanks to Mr. N. HAYASHI and Mr. N. SAIHARA for facilitating scanning electron microscopy.

\section{鋳型走査電顕法でしらべた重複輸入小動脈をもつラット腎糸球体}

$$
\text { 村上它 郎 }
$$

ラット腎糸球体の血管鋳型 1,856 個を走査電子顕微鏡でしらべ，非常にまれな重複輸入 小動脈をもつ腎糸球体 1 個を記載した. 
重複輸入小動脈は 葉間動脈の終枝からベつべつにおこり，1本の輸出小動脈をもつ被 膜下層系球体の血管極におわっていた，微解剖をおこなったところ，この異常な系球体は 吻合毛細血管からなるかなりはっきり独立した 三つの小葉にわけることができた. 微解 剖によってさらに 重複輸入小動脈は糸球体内でも分離しており, そして右の小動脈は中 と右の二つの小葉に, 左の小動脈は左の小葉のみに連なっていることが明らかにされた.

\section{References}

Boenig, H. : Beiträge zur Kenntnis der Vasa efferentia in der menschlichen Niere. Z. mikrosk.anat. Forsch. 39: 105-115 (1936).

Boyer, C. C.: The vascular pattern of the renal glomerulus as revealed by plastic reconstruction from serial sections. Anat. Rec. 125: 433-441 (1956).

Elias, H. : De structura glomeruli renalis. Anat. Anz. 104: 26-36 (1957).

Hall, B. V.: Further studies of the normal structure of the renal glomerulus. Proc. 6th Ann. Conf. Nephrotic Syndrome. New York, National Nephrosis Foundation 1955. (p. 1-39).

Irino, S., T. Ono, N. Takasugi, K. Toyota, K. Hiraki, K. Okada and T. Murakami : Application of the injection replica scanning electron microscope method to the study of the human autopsy samples. (Japanese). Igaku no Ayumi 91: 563-564 (1974).

Johnston, W. B.: A reconstruction of a glomerulus of human kidney. Anat. Anz, 16: 260-266 (1899).

Kojima, F. : A comparative anatomical study of renal vascular structure of the ungulate. (Japanese). Acta Schol. Med. Gifu 9: 3359-3377 (1961).

Lewis, O. J.: The vascular arrangement of the mammalian renal glomerulus as revealed by a study of its development. J. Anat. 92: 433-440 (1958).

Ljungqvist, A. and C. Lagergren : Normal intrarenal arterial pattern in adult and ageing human kidney. A micro-angiographical and histological study. J. Anat. 96: 285-300 (1962).

Moff at, D. B. and J. Fourman: The vascular pattern of the rat kidney. J. Anat. 97: 543-553 (1963).

Moore, R. A.: The circulation of the normal human kidney. Anat. Rec. 40: 51-60 (1928).

Murakami, T.: Application of the scanning electron microscope to the study of the fine distribution of the blood vessels. Arch. histol. jap. 32: 445-454 (1971).

- : Vascular arrangement of the rat renal glomerulus. A scanning electron microscope study of corrosion casts. Arch. histol. jap. 34: 87-107 (1972).

Murakami, T., M. Miyoshi and T. Fujita: Glomerular vessels of the rat kidney with special reference to double efferent arterioles. A scanning electron microscope study of corrosion casts. Arch. histol. jap. 33: 179-198 (1971).

Muto, R.: A comparative anatomy of renal vascular system of rodentia, especially renal vessels of guinea pig, rat and mouse (Japanese). Acta Schol. Med. Gifu 9: 537-553 (1961).

Nelson, B. T.: The number of glomeruli in the kidney of the adult rabbit. Anat. Rec. 23: 355-361 (1922).

Ohta, Y. and S. Tajiri : Cubical anatomy of several ducts and vessels by injection method of acrylic resin. I. On the arterial system of the kidney in some mammals. Okajimas Folia anat. jap. 26: 131-145 (1954).

Osathanondh, V. and E. L. Potter : Development of human kidney as shown by microdissection. V. Development of vascular pattern of glomerulus. Arch. Pathol. 82: 403-411 (1966).

Trabucco, A. and F. Marquez: Structure of the glomerular tuft. J. Urol. 67: 235-255 (1952).

Vimtrup, Bj.: On the number, shape, structure, and surface area of the glomeruli in the kidneys of man and mammals. Amer. J. Anat. 41: 123-151 (1928).

Wilmer, H. A.: The arrangement of the capillary tuft of the human glomerulus. An injection study. Anat. Rec. 80: 507-518 (1941). 
Zlábek, K.: Über dünne interkapillare Anastomosen im Nierenglomerulus der Ratte. Acta anat. 85: 177-189 (1973).

村上宅郎

T700 岡山市鹿田町 2-5-1

岡山大学医学部

第二解剖学教室
Dr. Takuro Murakami

Department of Anatomy

Okayama University School of Medicine

Okayama, 700 Japan 